\title{
Evaluation of source of corn silage and trace minerals on lactational performance and total-tract nutrient digestibility in Holstein cows
}

\author{
M. D. Miller, ${ }^{1} \oplus$ J. S. Lanier, ${ }^{2 *} \odot$ S. K. Kvidera, ${ }^{2}$ H. M. Dann, ${ }^{1}$ (๑) C. S. Ballard, ${ }^{1}$ and R. J. Grant ${ }^{1} \dagger{ }^{\oplus}$ \\ ${ }^{1}$ William H. Miner Agricultural Research Institute, Chazy, NY 12921 \\ ${ }^{2}$ Micronutrients USA LLC, Indianapolis, IN 46241
}

\begin{abstract}
We evaluated the effects of source of corn silage and trace minerals on lactational performance and totaltract digestibility (TTD) of nutrients in 16 Holstein cows averaging 82 (standard error $=3$ ) days in milk in a replicated $4 \times 4$ Latin square design with a 2 $\times 2$ factorial arrangement of treatments with $28-\mathrm{d}$ periods. The diets consisted [dry matter (DM) basis] of $55 \%$ conventional (CON) or brown midrib-3 (BM3) corn silage, $2 \%$ chopped wheat straw, and $43 \%$ grain mix with either sulfate (STM) or hydroxy (HTM) sources of copper, manganese, and zinc trace minerals. The targeted supplemental concentrations of copper, zinc, and manganese were 194, 1,657, and $687 \mathrm{mg} / \mathrm{d}$, respectively. The dietary treatments were CON-STM, CON-HTM, BM3-STM, and BM3-HTM. The dietary nutrient composition of the BM3 diets averaged $32.1 \%$ amylase neutral detergent fiber on an organic matter basis (aNDFom) and 6.9\% undigested neutral detergent fiber at $240 \mathrm{~h}$ (uNDF240om; \% of DM), and CON diets averaged $36.2 \%$ aNDFom and $8.6 \%$ uNDF240om (\% of DM). The average supplemental concentrations of copper, zinc, and manganese for the STM diets were 10,41 , and $64 \mathrm{mg} / \mathrm{kg}$, respectively, and the average supplemental concentrations of copper, zinc, and manganese for the HTM diets were 10, 40, and $62 \mathrm{mg} / \mathrm{kg}$, respectively. The average total dietary concentrations of copper, zinc, and manganese for the STM diets were 17,104 , and $60 \mathrm{mg} / \mathrm{kg}$, respectively, and the average total dietary concentrations of copper, zinc, and manganese for the HTM diets were 17, 91, and $66 \mathrm{mg} /$ $\mathrm{kg}$, respectively. Data were summarized by period and analyzed as a replicated Latin square design with fixed model effects for corn silage, trace minerals, corn silage $\times$ trace mineral interaction, period within replicated square, and replicated square using the MIXED procedure of SAS. Cow within replicated square was a
\end{abstract}

Received October 8, 2019.

Accepted December 15, 2019.

*Current address: Purina Animal Nutrition, Raleigh, NC 27615.

†Corresponding author: grant@whminer.com random effect. Cows fed the BM3 diets had greater dry matter intake (DMI) and milk yield (28.1 and 47.0 $\mathrm{kg} / \mathrm{d}$ ) than cows fed the CON diets (27.5 and 44.7 $\mathrm{kg} / \mathrm{d})$. We found no significant interaction between corn silage and trace minerals for DMI and milk yield. Cows fed the HTM diets $(28.1 \mathrm{~kg} / \mathrm{d})$ had a greater DMI than cows fed the STM diets $(27.5 \mathrm{~kg} / \mathrm{d})$. Cows fed the BM3 diets had greater TTD of DM and OM (72.8 and $74.1 \%$ of $\mathrm{DM}$ ) than cows fed the CON diets (71.1 and $72.3 \%$ of DM). Cows fed the HTM diets had a tendency for greater TTD of aNDFom than cows fed the STM diets (56.8 vs. $54.9 \%$ of DM). Cows fed the CON diets ruminated longer during the day than cows fed the BM3 diets (524 vs. $496 \mathrm{~min} / \mathrm{d}$ ). Corn silage with greater NDF digestibility and lower uNDF240om enhanced DMI, milk yield, and TTD of DM and OM, and hydroxy trace minerals improved DMI and tended to improve TTD of aNDFom. The source of corn silage and trace minerals should be taken into consideration when formulating diets for high-producing dairy cows. Key words: trace mineral, corn silage, total-tract digestibility, dairy cattle

\section{INTRODUCTION}

The chemical and physical characteristics of forage fiber influence rumen fermentation and digestibility (Allen and Mertens, 1988). Corn silage is a major contributor of the forage fiber in dairy cattle diets, and hybrids such as brown midrib corn silage have greater NDF digestibility, lower lignin content, and less indigestible NDF than conventional corn silage (Hassanat et al., 2017). Undigested NDF on an OM basis (uNDF240om) measures the indigestible NDF following in vitro fermentation for $240 \mathrm{~h}$ (Raffrenato et al., 2018). Undigested NDF has been related to digestion and passage kinetics, gut fill, and physical effectiveness (Nousiainen et al., 2003; Cotanch et al., 2014). In previous studies, cows fed diets with brown midrib corn silage had greater DMI and lower rumen fill than cows fed diets with conventional corn silage. This advantage of brown midrib over conventional corn silage in DMI and fill is attributable to a lower indigestible NDF fraction 
and greater fiber passage rates (Oba and Allen, 1999a, 2000a,c; Hassanat et al., 2017).

Trace minerals are required for the proper function of rumen microorganisms, but solubilization in the rumen may release free metal too fast, allowing interactions with antagonists and reducing the bioavailability of the mineral. Solubility varies among sources of trace minerals, such as between hydroxy and sulfate, and can affect rumen fermentation. The free metals from solubilized minerals may have direct negative effects on cellulolytic bacteria, or they may bind to undigested fractions (e.g., fiber fractions) that pass from the rumen undigested (Torre et al., 1991; Genther and Hansen, 2015; Faulkner et al., 2017). Rumen solubility of hydroxy $\mathrm{Cu}$ and $\mathrm{Mn}$ is less than sulfate sources, but they have similar solubilities at a lower $\mathrm{pH}$ in the abomasum (Spears et al., 2004; Genther and Hansen, 2015). Earlier research has shown that Zn from hydroxy and sulfate sources has variable solubility (Cao et al., 2000; Genther and Hansen, 2015). However, a recent study reported that Zn sulfate had greater rumen solubility than Zn hydroxychloride (Caldera et al., 2019). Feeding sulfate sources of $\mathrm{Cu}, \mathrm{Mn}$, and $\mathrm{Zn}$ minerals decreased total-tract NDF digestibility compared with hydroxy $\mathrm{Cu}, \mathrm{Mn}$, and $\mathrm{Zn}$ minerals in forage- and byproduct-based dairy cattle diets (Faulkner and Weiss, 2017). The forage-based diets resulted in a greater difference in NDF digestibility between the sulfate and hydroxy trace minerals than the byproduct-based diets. This finding suggests that the source of NDF influences the potential effect of source of trace minerals on NDF digestibility.

To date, no study has assessed the interaction between the sources of forage fiber and trace minerals in diets fed to lactating dairy cows. The objective of this study was to evaluate the effect of the source of corn silage and trace minerals on lactation performance and total-tract digestibility of nutrients in Holstein cows. Our hypothesis was that a sulfate source of trace minerals would negatively affect total-tract fiber digestibility and the effect would be greater in the diets with conventional corn silage.

\section{MATERIALS AND METHODS}

\section{Experimental Design, Diets, and Management of Cows}

All experimental procedures involving animals were approved by the William H. Miner Agricultural Research Institute Animal Care and Use Committee. The study was conducted at the William H. Miner Agricultural Research Institute (Chazy, NY) in the Charles J. Sniffen Dairy Research and Education Complex. Sixteen lactating Holstein cows (8 ruminally cannulated) averaging $82 \pm 3$ (mean \pm SE) DIM at the beginning of the experiment were blocked by cannulation status, DIM, and milk production and were used in a replicated $4 \times 4$ Latin square design with a $2 \times 2$ factorial arrangement of treatments. The study had 28-d periods. Each square was conducted concurrently; the first $17 \mathrm{~d}$ served as an adaptation period, and the last $11 \mathrm{~d}$ served as the collection period. Cows were enrolled on the study $14 \mathrm{~d}$ before period 1 began and were fed a TMR with no supplemental trace minerals or monensin (Elanco Animal Health, Greenfield, IN).

Dietary treatments (Table 1) were formulated to contain either conventional (CON) or brown midrib-3 corn silage (BM3) and either a sulfate (STM) source of $\mathrm{Cu}, \mathrm{Zn}$, and $\mathrm{Mn}$ or hydroxy trace minerals (HTM; IntelliBond $\mathrm{Cu}, \mathrm{Zn}$, and $\mathrm{Mn}$; Micronutrients USA LLC, Indianapolis, IN). The objective for substitution of corn silage simply on a 1:1 DM basis was to allow the differences in fiber fractions among the diets to be determined primarily by the source of corn silage. The targeted supplemental concentrations of $\mathrm{Cu}, \mathrm{Zn}$, and $\mathrm{Mn}$ were 194, 1,657, and $687 \mathrm{mg} / \mathrm{d}$, respectively. The 4 dietary treatments were $\mathrm{CON}$ and sulfate trace minerals (CON-STM), CON and hydroxy trace minerals (CON-HTM), BM3 and sulfate trace minerals (BM3-STM), and BM3 and hydroxy trace minerals (BM3-HTM). Diets were formulated using Cornell Net Carbohydrate Protein System biology (version 4.8; AMTS.Cattle.Professional, Agricultural Modeling \& Training systems, LLC, Groton, NY). Inputs used for diet formulation included $29.9 \mathrm{~kg} / \mathrm{d}$ DMI, $54 \mathrm{~kg} / \mathrm{d}$ milk with $3.60 \%$ fat and $3.05 \%$ true protein, and $750 \mathrm{~kg}$ of BW. Cows were fed the diets as TMR for ad libitum intake (approximately $1.05 \times$ expected intake) once per day (fed at 1400 h; Calan Data Ranger, American Calan Inc., Northwood, NH) in a tiestall barn equipped with individual feed boxes.

\section{Data Collection, Sample Procedures, and Analytical Methods}

Forages, diets, and orts were collected 3 times per week from d 1 to 17 and daily from d 18 to 28 . Grain mixes were collected once per week from d 1 to 17 and daily from d 18 to 28 . A portion of each sample was dried in a forced-air oven at $105^{\circ} \mathrm{C}$ to constant weight for determination of DM. Diets were adjusted for changes in DM content of the feed ingredients when a feed ingredient DM value was outside the range of the $\mathrm{DM}$ mean \pm 1.2 standard deviations or a new feed ingredient source was used or delivered.

Starting on d 18 of each period, a portion of the feed ingredients, diets, and orts collected daily was stored frozen at $-20^{\circ} \mathrm{C}$, and then composited by period by 
Table 1. Ingredient composition (\% of DM) of diets fed to lactating Holstein cows

\begin{tabular}{|c|c|c|c|c|}
\hline \multirow[b]{3}{*}{ Item } & \multicolumn{4}{|c|}{$\operatorname{Diet}^{1}$} \\
\hline & \multicolumn{2}{|c|}{$\mathrm{CON}$} & \multicolumn{2}{|c|}{ BM3 } \\
\hline & STM & HTM & STM & HTM \\
\hline Conventional corn silage & 54.56 & 54.56 & - & - \\
\hline Brown mid-rib corn silage & - & - & 54.55 & 54.55 \\
\hline Straw, chopped wheat & 2.27 & 2.27 & 2.27 & 2.27 \\
\hline Beet pulp, pelleted & 6.82 & 6.82 & 6.82 & 6.82 \\
\hline Corn meal & 2.67 & 2.67 & 2.67 & 2.67 \\
\hline \multicolumn{5}{|l|}{ Concentrate mix } \\
\hline Soybean hulls & 7.31 & 7.31 & 3.07 & 3.07 \\
\hline 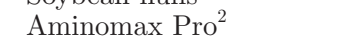 & 6.59 & 6.59 & 5.27 & 5.27 \\
\hline Soybean meal & 5.30 & 5.30 & 6.67 & 6.67 \\
\hline Corn meal & 1.71 & 1.71 & 5.60 & 5.60 \\
\hline Canola meal & 2.69 & 2.69 & 4.02 & 4.02 \\
\hline $99 \%$ sugar & 1.41 & 1.41 & 1.41 & 1.41 \\
\hline Dried distillers grains & 1.34 & 1.34 & - & - \\
\hline BergaFat $^{3}$ & 1.21 & 1.21 & 1.21 & 1.21 \\
\hline Calcium carbonate & 1.10 & 1.11 & 1.10 & 1.11 \\
\hline PGI Amino Enhancer ${ }^{2}$ & 0.86 & 0.86 & 1.17 & 1.17 \\
\hline Molasses & 0.82 & 0.82 & 0.82 & 0.82 \\
\hline Sodium sesquicarbonate & 0.73 & 0.73 & 0.73 & 0.73 \\
\hline Potassium carbonate 4 & 0.59 & 0.59 & 0.59 & 0.59 \\
\hline Energizer Gold ${ }^{5}$ & 0.59 & 0.59 & 0.59 & 0.59 \\
\hline Salt & 0.38 & 0.38 & 0.38 & 0.38 \\
\hline Urea & 0.37 & 0.37 & 0.37 & 0.37 \\
\hline Magnesium oxide & 0.31 & 0.31 & 0.31 & 0.31 \\
\hline Monodicalcium phosphate & 0.12 & 0.12 & 0.12 & 0.12 \\
\hline Selenium yeast $0.06 \%^{6}$ & 0.05 & 0.05 & 0.05 & 0.05 \\
\hline Calcium chloride & 0.04 & 0.04 & 0.04 & 0.04 \\
\hline Vitamin $\mathrm{E}^{7}$ & 0.03 & 0.03 & 0.03 & 0.03 \\
\hline Clarifly $0.67 \%^{8}$ & 0.03 & 0.03 & 0.03 & 0.03 \\
\hline Meta Smart ${ }^{9}$ & 0.02 & 0.02 & 0.04 & 0.04 \\
\hline Vitamin $\mathrm{E}^{10}$ & 0.02 & 0.02 & 0.02 & 0.02 \\
\hline Smartamine ${ }^{9}$ & 0.01 & 0.01 & 0.01 & 0.01 \\
\hline Copper sulfate & 0.004 & - & 0.004 & - \\
\hline Manganese sulfate & 0.012 & - & 0.012 & - \\
\hline Zinc sulfate & 0.017 & - & 0.017 & - \\
\hline Hydroxy copper ${ }^{11}$ & - & 0.002 & - & 0.002 \\
\hline Hydroxy zinc ${ }^{11}$ & - & 0.009 & - & 0.009 \\
\hline Hydroxy manganese ${ }^{11}$ & - & 0.011 & - & 0.011 \\
\hline Vitamin $\mathrm{A}^{12}$ & 0.0003 & 0.0003 & 0.0003 & 0.0003 \\
\hline Vitamin $D^{13}$ & 0.0002 & 0.0002 & 0.0002 & 0.0002 \\
\hline Cobalt carbonate & 0.0002 & 0.0002 & 0.0002 & 0.0002 \\
\hline Potassium iodide & 0.0001 & 0.0001 & 0.0001 & 0.0001 \\
\hline Total & 100 & 100 & 100 & 100 \\
\hline
\end{tabular}

${ }^{1}$ Diets containing either conventional corn silage (CON) or brown midrib corn silage (BM3) with either sulfate trace minerals (STM) or hydroxy trace minerals (HTM).

${ }^{2}$ Poulin Grain (Newport, VT).

${ }^{3}$ Berg + Schmidt America LLC (Libertyville, IL).

${ }^{4}$ DCAD Plus; Arm and Hammer Animal Nutrition (Ewing, NJ).

${ }^{5}$ IFFCO (Malaysia) Sdn Bhd, Sharjah, United Arab Emirates.

${ }^{6}$ Co-operative Feed Dealers Inc. (Conklin, NY).

${ }^{7}$ Contained 500,000 IU of vitamin E/kg, \% of DM.

${ }^{8}$ Central Garden and Pet Company (Schaumburg, IL).

${ }^{9}$ Adisseo USA Inc. (Alpharetta, GA).

${ }^{10}$ Contained 8,816 IU of vitamin $\mathrm{E} / \mathrm{kg}, \%$ of DM.

${ }^{11}$ Intellibond $\mathrm{Cu}, \mathrm{Zn}, \mathrm{Mn}$ (Micronutrients USA LLC, Indianapolis, IN).

${ }^{12}$ Contained $1,000,000$ IU of vitamin $\mathrm{A} / \mathrm{g}, \%$ of DM.

${ }^{13}$ Contained 500,000 IU of vitamin $\mathrm{D} / \mathrm{g}, \%$ of $\mathrm{DM}$. 
combining equal volumes of the daily as-fed samples. The composites of feed ingredients were analyzed for chemical composition (CPM Plus; Cumberland Valley Analytical Services Inc., Waynesboro, PA). Analyses included DM, ash (method 942.05; AOAC International, 2012), OM (method 942.05; AOAC International, 2012), CP (method 990.03; AOAC International, 2012), soluble protein according to Krishnamoorthy et al. (1982), fat (method 2003.05; AOAC International, 2012), ADF (method 973.18; AOAC International, 2012), NDF using $\alpha$-amylase (Van Soest et al., 1991), ADL (Goering and Van Soest, 1970), starch according to Hall (2009), sugar as ethanol soluble carbohydrates according to DuBois et al. (1956), and minerals (method 985.01; AOAC International, 2012).

Fermentation analysis was performed on the ensiled forage composite samples (Cumberland Valley Analytical Services Inc.). A 25-g wet sample was diluted with $200 \mathrm{~mL}$ of water, blended, and filtered through 20- to $25-\mu \mathrm{m}$ filter paper. The extract was used to determine $\mathrm{pH}$ with a Mettler DL12 $\mathrm{pH}$ Titrator (Mettler-Toledo LLC, Columbus, $\mathrm{OH}$ ) and $\mathrm{NH}_{3}-\mathrm{N}$ in a $1: 3$ ratio of extract and water with a Labconco Rapidstill II model 65200 analyzer (Labconco, Kansas City, MO). Lactic acid was determined in a 1:1 ratio of extract and water with a YSI 2700 Select Biochemistry Analyzer (YSI Inc., Yellow Springs, OH). Acetic, propionic, butyric, and isobutyric acid concentrations were determined using a Perkin Elmer AutoSystem gas chromatograph with a Restek column packed with Stabilwax-DA (Perkin Elmer, Shelton, CT).

Fiber characteristics and NDF digestibility at $30 \mathrm{~h}$ (NDFd at $30 \mathrm{~h}$ ) were determined on the forage and grain composite samples (Cumberland Valley Analytical Services Inc.). Undigested NDF at 30, 120, and 240 h (uNDF30om, uNDF120om, uNDF240om, respectively) for forages and uNDF at 12,72 , and $120 \mathrm{~h}$ (uNDF12om, uNDF72om, and uNDF120om, respectively) for grains were assessed using a Tilley-Terry rumen fermentation system (Raffrenato et al., 2018; Cumberland Valley Analytical Services Inc.). Starch digestibility at $7 \mathrm{~h}$ (Hall, 2009; Cumberland Valley Analytical Services Inc.) was determined on the period composite samples of corn silage and grain mixes. A portion of the period composite for forage and grain mixes was used to determine particle size distribution on a DM basis $\left(55^{\circ} \mathrm{C}\right.$ ) by dry vertical sieving (Ro-Tap testing sieve shaker model B; W. S. Tyler Combustion Engineering, Inc., Mentor, OH). The physical effectiveness factor (pef) was defined as the fraction of particles retained on the 1.18-mm screen or greater. Physically effective NDF (peNDF) of a forage or diet was calculated as the product of its NDF content and its pef (Mertens, 1997).
Individual DMI was determined by recording feed offered and refused daily. Samples of diets and orts were collected daily (d 18 to 28 ) during each period, and a portion of each sample was dried in a forced-air oven at $105^{\circ} \mathrm{C}$ to constant weight for DM determination.

Cows were milked 3 times daily $(0430,1230$, and 2030 h) in a double-12 parallel milking parlor (Xpressway Parallel Stall System; Bou-Matic, Madison, WI). Milk yield was recorded electronically at each milking daily (d 18 to 28) for each period (ProVantage Information Management System; Bou-Matic). Milk samples from 6 consecutive milkings for each cow were collected on d 25 and 26 of each period. The milk samples were analyzed for fat, true protein, lactose (anhydrous), solids nonfat, urea nitrogen, and de novo, mixed, and preformed fatty acids by mid-infrared procedures (CombiScope FTIR 300 Hp; Delta Instruments, Drachten, the Netherlands; Wojciechowski and Barbano, 2016; Wojciechowski et al., 2016; Woolpert et al., 2016). Somatic cell count was analyzed by flow cytometry (CombiScope FTIR $300 \mathrm{Hp}$, Delta Instruments). Daily milk samples were mathematically composited after analysis in proportion to milk yield at each sampling. Somatic cell count was transformed and analyzed as SCS according to Shook (1993) using the equation: SCS $=\log _{2}(\mathrm{SCC} / 100)+$ 3 , where SCC was in units of 1,000 cells $/ \mathrm{mL}$. Energycorrected milk was calculated using a formula modified to account for the use of true protein instead of total protein (Tyrrell and Reid, 1965; Mark Stephenson, University of Wisconsin; https://dairymarkets.org/ PubPod/Reference/Library/Energy\%20Corrected\%20 Milk): $0.327 \times \mathrm{kg}$ of milk $+12.95 \times \mathrm{kg}$ of fat $+7.65 \times$ $\mathrm{kg}$ of true protein.

Feed efficiency $(\mathrm{kg} / \mathrm{kg})$ was calculated and expressed as milk per DMI and ECM per DMI for d 18 through d 28 of each period. Body weight was measured (Allweigh computerized scale; Allweigh Scale System Inc., Red Deer, AB, Canada) and BCS was assigned in 0.25-unit increments on a scale of 1 to 5 (Ferguson et al., 1994) by 2 trained individuals independently at the beginning of the study and on d 28 of each period.

Total-tract digestibility of DM, OM, aNDFom, and starch was determined on d 20 to 23 of each period. Samples of diets and orts were collected on d 20 to 23. Representative samples of the diets were taken and composited by treatment. Representative samples of the orts were collected for each cow and composited by cow. Fecal grab samples were collected d 21 through 23 for each period so that every $3 \mathrm{~h}$ in a 24 -h period were represented ( 8 samples total). Fecal samples from each cow were composited by combining approximately $118 \mathrm{~mL}$ of wet feces from each time point. Samples of diets, orts, and feces were frozen at $-20^{\circ} \mathrm{C}$, dried in a forced-air oven at $55^{\circ} \mathrm{C}$ for $48 \mathrm{~h}$, ground to pass 
through a 1-mm screen (Wiley mill; Arthur H. Thomas, Philadelphia, PA), and submitted for chemical analysis (Cumberland Valley Analytical Services Inc.). Composite samples of diets (by period), orts (by cow and period), and feces (by cow and period) were analyzed for DM, OM, ADF, aNDFom, and starch (Van Soest et al., 1991; Hall, 2009; method 942.05, AOAC International, 2012; method 973.18, AOAC International, 2012). The uNDF240om concentration was used as an internal marker. Total-tract digestibility was calculated by the ratio technique using the concentrations of the nutrients and uNDF240om in the diet and feces (Maynard et al., 1979). The nutrient content of the diet used in the digestibility calculation was adjusted for each cow based on the nutrient composition of the diet offered and refused. Digested nutrients were calculated by nutrient intake multiplied by the total-tract digestibility of that nutrient.

Cows were monitored for chewing activity (eating or ruminating) and posture (standing or lying) every 5 min for 3 consecutive 24-h periods (d 23 to 25 ) for each study period. Chewing observations continued while cows were being milked, for a total of $72 \mathrm{~h}$ of chewing behavior observations. Total time (in min) spent on each activity for each day was quantified by multiplying the total number of observations for that activity by $5 \mathrm{~min}$. The number of bouts of eating and the length of each bout were recorded. A bout was defined as at least 2 consecutive observations of eating behavior not interrupted by more than 2 observations of a different behavior (Black et al., 2016).

\section{Statistical Analysis}

Data from the analysis of feed ingredients and diets were analyzed using the MEANS procedure of SAS (version 9.4; SAS Institute Inc., Cary, NC), and were reported as descriptive statistics (mean \pm standard error).

Two cows were removed from the final data set used for statistical analysis. One of the cows failed to respond to antibiotic and supportive therapy for mastitis that was caused by Enterobacter (Quality Milk Production Services, Ithaca, NY). The other cow had severe digestive upset that caused a dramatic decrease in feed intake and milk production during period 4 , and she never recovered. Thus, 14 cows ( 8 cannulated cows and 6 non-cannulated cows) were used in the statistical analysis.

Data with a normal distribution (DMI, milk yield and composition, feed efficiency, BW, BCS, chewing behaviors, and total-tract digestibility) were analyzed as a replicated Latin square design (Latin rectangle) with fixed effects of corn silage, trace mineral, corn silage $\times$ trace mineral interaction, period within replicated square, and replicated square using the MIXED procedure of SAS. Cow within replicated square was a random effect. Repeated measurements of performance data from the collection period (e.g., DMI, milk yield and composition, feed efficiency, chewing behaviors, and total-tract digestibility) were reduced to period means for each cow before statistical analysis. Significance was declared at $P \leq 0.05$ and trends at $0.05<P \leq 0.10$.

\section{RESULTS AND DISCUSSION}

\section{Dietary and Ingredient Nutrient Composition}

Chemical composition and in vitro NDF and starch digestibility of the ingredients and concentrate mixes are presented in Tables 2, 3, 4, and 5. Neutral detergent fiber averaged 41.9 and $39.1 \%$ for CON and BM3 corn silage, respectively. The starch content of the CON corn silage was lower than that of the BM3 corn silage due to an unexpected change in starch content during periods 3 and 4 compared with periods 1 and 2 (29.6 vs. $35.6 \%$ of $\mathrm{DM})$. In vitro starch digestibility averaged 81.2 and $80.6 \%$ of starch for CON and BM3 corn silage, respectively. The NDFd of the BM3 corn silage was 9.7 percentage units greater at $30 \mathrm{~h}$ compared with that of the CON corn silage (68.4 vs. $58.7 \%$ of aNDFom, respectively). The uNDF240om of the BM3 corn silage was 2.8 percentage units lower than that of the CON corn silage ( 7.8 vs. $10.6 \%$ of DM, respectively). These relative differences were expected based on previous literature comparing BM3 and conventional corn silage hybrids (Oba and Allen, 2000c; Hassanat et al., 2017).

The calculated chemical composition and fiber fractions of the treatment diets (based on analysis of individual ingredients) are shown in Tables 6 and 7. The CON diets had numerically greater aNDFom and lower starch content than the BM3 diets, due to the greater aNDFom and lower starch content of the CON corn silage ( 36.2 vs. $32.1 \%$ of DM; 21.9 vs. $26.2 \%$ of DM, respectively). The NDFd at $30 \mathrm{~h}$ was numerically greater for the BM3 diets than for the CON diets, and the uNDF240om was numerically lower for the BM3 diets than for the CON diets $(62.0$ vs. $55.7 \%$ of aNDFom; 6.9 vs. $8.6 \%$ of $\mathrm{DM}$, respectively). The overall TMR composition primarily reflected the compositional differences between the sources of corn silage.

The supplemental and total dietary trace mineral concentrations were numerically similar among diets. The concentrations of trace minerals were kept constant across diets, but the source was either STM or HTM, as shown in Table 8. The concentrations of trace minerals were chosen to be similar to on-farm diets for high-producing dairy cows and exceeded NRC (2001) 
Table 2. Data (mean $\pm \mathrm{SD}$ ) characterizing the analyzed chemical composition of feed ingredients fed to lactating Holstein cows

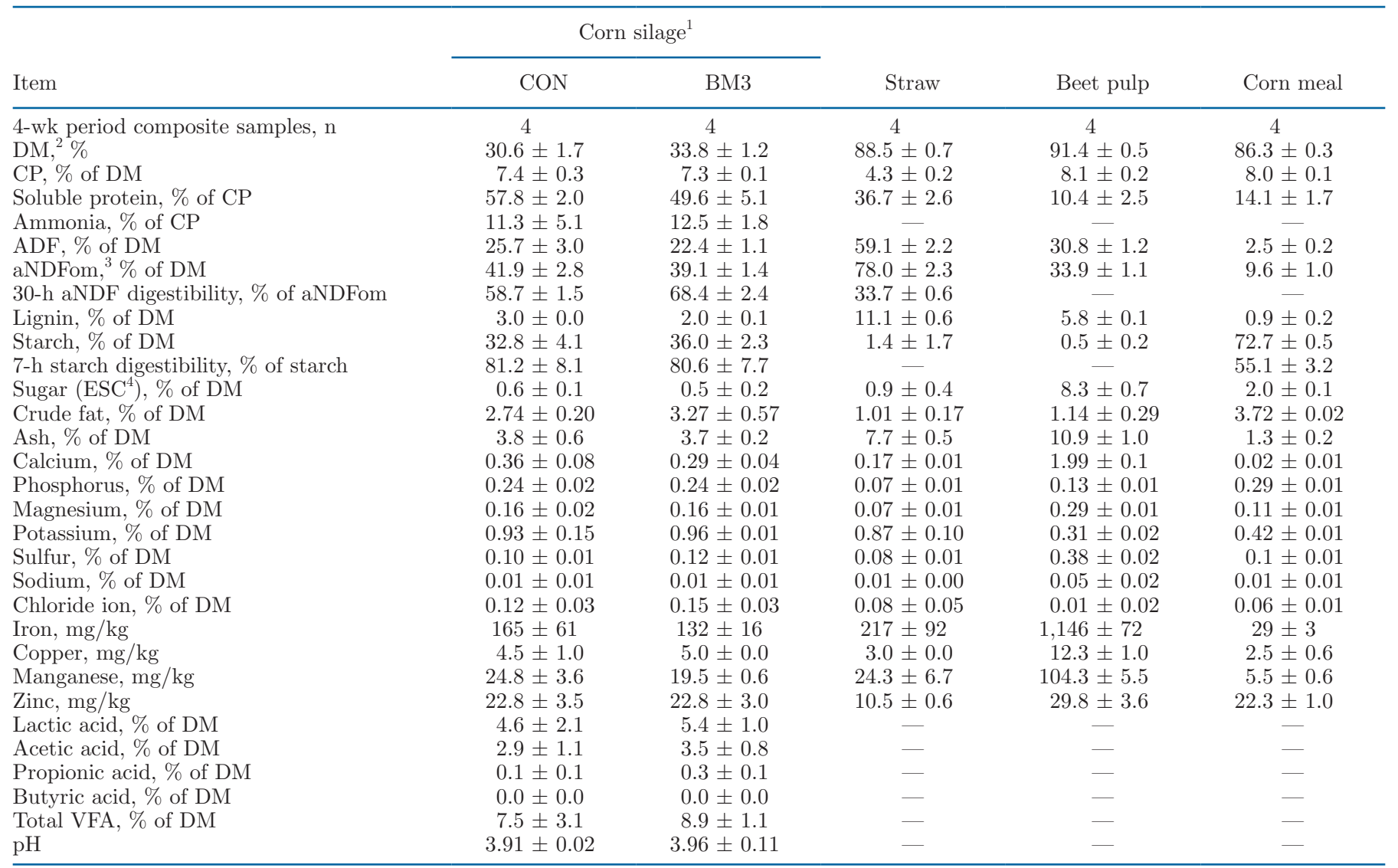

${ }^{1}$ Conventional corn silage (CON) or brown midrib corn silage (BM3).

${ }^{2}$ For DM analysis, $\mathrm{n}=44$ for CON and BM3 corn silage and straw; $\mathrm{n}=8$ for beet pulp and corn meal.

${ }^{3}$ Amylase NDF on an OM basis.

${ }^{4}$ Ethanol-soluble carbohydrates.

guidelines. The average total dietary mineral content for $\mathrm{Cu}, \mathrm{Mn}$, and $\mathrm{Zn}$ was $472,1,757$, and $2,699 \mathrm{mg} / \mathrm{d}$, respectively. The average total dietary mineral content for $\mathrm{Cu}, \mathrm{Mn}$, and $\mathrm{Zn}$ for Faulkner and Weiss (2017) was $477,1,812$, and $1,817 \mathrm{mg} / \mathrm{d}$, respectively. The $\mathrm{Cu}$ and $\mathrm{Mn}$ contents were very similar to Faulkner and
Weiss (2017). The intake of Zn was greater in our study than in that of Faulkner and Weiss (2017), but this was expected because we were formulating for a higher concentration of the mineral (63 vs. $35 \mathrm{mg} / \mathrm{kg}$ ).

As expected, the particle size distribution among the diets was similar (Table 9). The diets had a pef

Table 3. Data (mean \pm SD) characterizing the fiber fractions of feed ingredients fed to lactating Holstein cows

\begin{tabular}{|c|c|c|c|c|c|}
\hline Item & \multicolumn{2}{|c|}{ Corn silage $e^{1}$} & Straw & Beet pulp & Corn meal \\
\hline 4-wk period composite samples, $n$ & 4 & 4 & 4 & 4 & 4 \\
\hline Undigested NDFom at $12 \mathrm{~h}, \%$ of DM & - & - & - & $12.9 \pm 4.8$ & $7.7 \pm 0.6$ \\
\hline Undigested NDFom at $30 \mathrm{~h}, \%$ of DM & $17.3 \pm 1.6$ & $12.3 \pm 0.8$ & $51.7 \pm 1.4$ & - & - \\
\hline Undigested NDFom at $72 \mathrm{~h}, \%$ of DM & - & - & - & $6.2 \pm 2.0$ & $3.0 \pm 0.4$ \\
\hline Potentially digestible NDF ${ }^{3} \%$ of aNDFom & $74.8 \pm 0.8$ & $80.1 \pm 1.0$ & $50.2 \pm 1.5$ & - & - \\
\hline
\end{tabular}

${ }^{1}$ Conventional corn silage (CON) or brown midrib corn silage (BM3).

${ }^{2}$ Amylase NDF on an OM basis.

${ }^{3}$ Potentially digestible NDF $=$ aNDFom - undigested NDFom at $240 \mathrm{~h}$. 
Table 4. Data (mean $\pm \mathrm{SD}$ ) characterizing the analyzed chemical composition of concentrate mixes fed to lactating Holstein cows

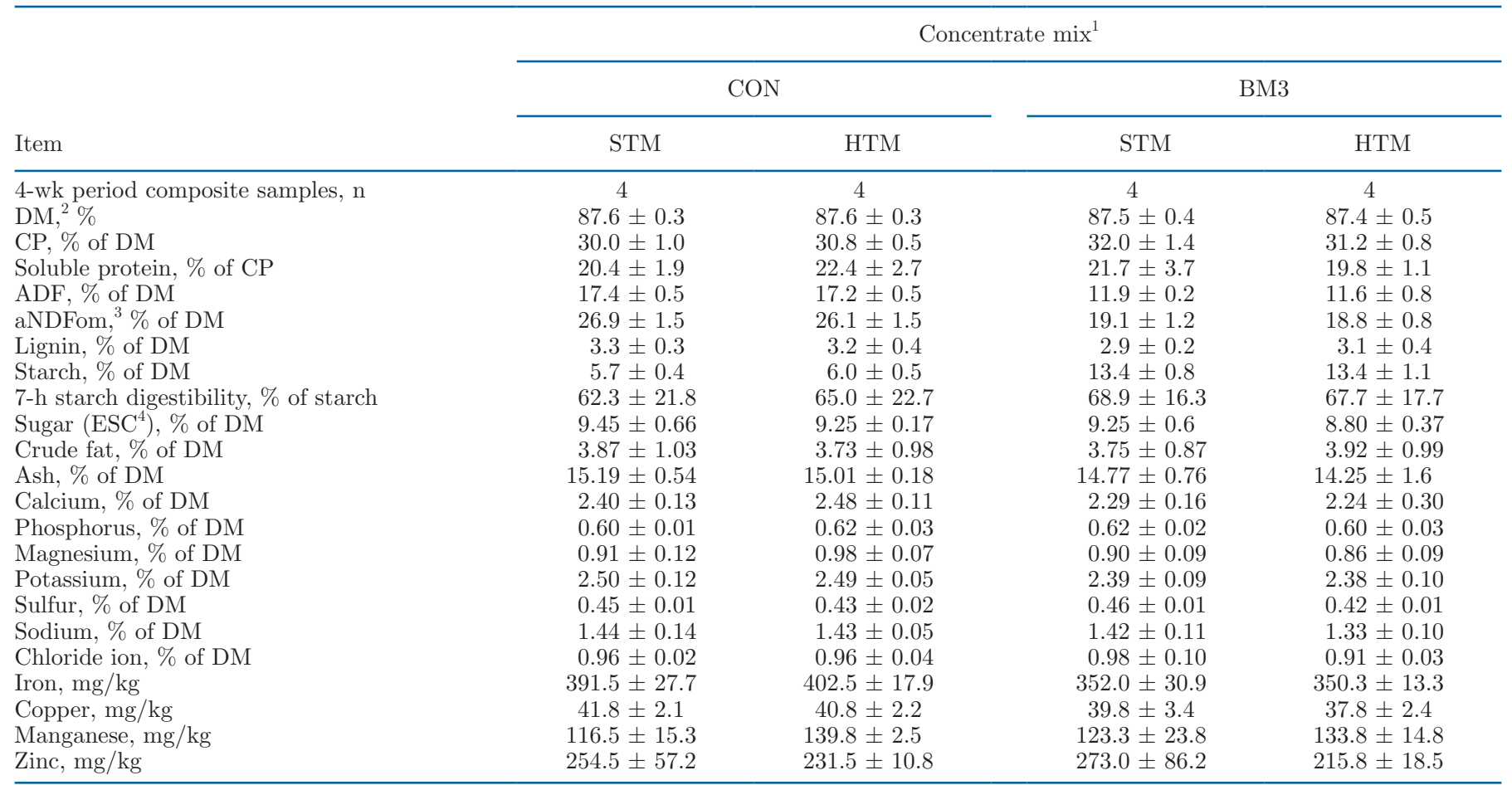

${ }^{1}$ Concentrate mixes for diets containing either conventional corn silage (CON) or brown midrib corn silage (BM3) with either sulfate trace minerals (STM) or hydroxy trace minerals (HTM).

${ }^{2}$ For DM analysis, $\mathrm{n}=8$ for concentrate mixes.

${ }^{3}$ Amylase NDF on an OM basis.

${ }^{4}$ Ethanol-soluble carbohydrates.

of approximately 0.68. The peNDF content of the CON diets, measured according to Mertens (1997), were greater than that of BM3 diets $(24.1 \%$ vs. $21.9 \%$, respectively), a finding that can be attributed to differences in aNDFom content in each diet, and not particle size distribution.

In summary, we anticipated that response to diet would be a function of the source of corn silage and trace minerals. Although we had intended for the silage to differ mainly in NDF digestibility, the unexpected change in starch content during the study means that any measured effect of corn silage will be a combination of NDF and starch concentrations.

\section{Lactational Performance}

Findings for DMI, BW, BCS, and nutrient intakes are presented in Table 10. The interaction of corn silage

Table 5. Data (mean $\pm \mathrm{SD}$ ) characterizing the fiber fractions of concentrate mixes fed to lactating Holstein cows

\begin{tabular}{|c|c|c|c|c|}
\hline \multirow[b]{3}{*}{ Item } & \multicolumn{4}{|c|}{ Concentrate $\operatorname{mix}^{1}$} \\
\hline & \multicolumn{2}{|c|}{$\mathrm{CON}$} & \multicolumn{2}{|c|}{ BM3 } \\
\hline & STM & HTM & STM & HTM \\
\hline 4-wk period composite samples, $\mathrm{n}$ & 4 & 4 & 4 & 4 \\
\hline aNDFom, ${ }^{2} \%$ of DM & $26.9 \pm 1.5$ & $26.1 \pm 1.5$ & $19.1 \pm 1.2$ & $18.8 \pm 0.8$ \\
\hline Undigested NDFom at $12 \mathrm{~h}, \%$ of DM & $12.5 \pm 1.4$ & $12.8 \pm 3.8$ & $9.6 \pm 1.6$ & $9.3 \pm 1.5$ \\
\hline Undigested NDFom at $72 \mathrm{~h}, \%$ of DM & $5.0 \pm 0.4$ & $5.1 \pm 0.5$ & $4.9 \pm 0.5$ & $4.7 \pm 0.4$ \\
\hline Undigested NDFom at $120 \mathrm{~h}, \%$ of DM & $4.4 \pm 0.4$ & $4.5 \pm 0.3$ & $4.1 \pm 0.3$ & $4.2 \pm 0.2$ \\
\hline
\end{tabular}

${ }^{1}$ Concentrate mixes for diets containing either conventional corn silage (CON) or brown midrib corn silage (BM3) with either sulfate trace minerals (STM) or hydroxy trace minerals (HTM).

${ }^{2}$ Amylase NDF on an OM basis. 
Table 6. Calculated diet composition (mean $\pm \mathrm{SD}$ ) based on chemical analysis of ingredients fed to lactating Holstein cows

\begin{tabular}{|c|c|c|c|c|}
\hline \multirow[b]{3}{*}{ Item } & \multicolumn{4}{|c|}{$\operatorname{Diet}^{1}$} \\
\hline & \multicolumn{2}{|c|}{$\mathrm{CON}$} & \multicolumn{2}{|c|}{ BM3 } \\
\hline & STM & HTM & STM & HTM \\
\hline$\overline{\mathrm{DM}}{ }^{2} \%$ & $43.5 \pm 2.0$ & $43.7 \pm 1.6$ & $45.9 \pm 1.2$ & $46.4 \pm 1.3$ \\
\hline $\mathrm{CP}, \%$ of $\mathrm{DM}$ & $15.0 \pm 0.4$ & $15.3 \pm 0.3$ & $15.6 \pm 0.5$ & $15.4 \pm 0.2$ \\
\hline Soluble protein, $\%$ of $\mathrm{CP}$ & $40.3 \pm 1.9$ & $41.0 \pm 2.0$ & $36.3 \pm 4.0$ & $35.6 \pm 3.4$ \\
\hline $\mathrm{ADF}, \%$ of DM & $23.4 \pm 1.8$ & $23.3 \pm 1.8$ & $19.7 \pm 0.7$ & $19.6 \pm 0.9$ \\
\hline aNDFom, ${ }^{3} \%$ of DM & $36.3 \pm 2.1$ & $36.0 \pm 2.1$ & $32.1 \pm 0.9$ & $32.0 \pm 0.9$ \\
\hline Lignin, \% of DM & $3.4 \pm 0.1$ & $3.4 \pm 0.1$ & $2.7 \pm 0.1$ & $2.8 \pm 0.1$ \\
\hline Starch, $\%$ of DM & $21.8 \pm 2.4$ & $21.9 \pm 2.4$ & $26.2 \pm 1.3$ & $26.1 \pm 1.2$ \\
\hline Sugar $\left(\mathrm{ESC}^{4}\right), \%$ of DM & $4.1 \pm 0.3$ & $4.1 \pm 0.1$ & $4.0 \pm 0.3$ & $3.9 \pm 0.2$ \\
\hline Crude fat, $\%$ of DM & $3.0 \pm 0.4$ & $3.0 \pm 0.4$ & $3.2 \pm 0.6$ & $3.3 \pm 0.5$ \\
\hline Ash, \% of DM & $8.12 \pm 0.33$ & $8.06 \pm 0.43$ & $7.91 \pm 0.28$ & $7.74 \pm 0.62$ \\
\hline Calcium. \% of DM & $1.14 \pm 0.07$ & $1.17 \pm 0.02$ & $1.07 \pm 0.05$ & $1.05 \pm 0.10$ \\
\hline Phosphorus, \% of DM & $0.35 \pm 0.01$ & $0.36 \pm 0.0$ & $0.36 \pm 0.01$ & $0.35 \pm 0.01$ \\
\hline Magnesium, $\%$ of DM & $0.41 \pm 0.04$ & $0.44 \pm 0.02$ & $0.41 \pm 0.03$ & $0.40 \pm 0.03$ \\
\hline Potassium, $\%$ of DM & $1.40 \pm 0.11$ & $1.40 \pm 0.10$ & $1.38 \pm 0.03$ & $1.38 \pm 0.03$ \\
\hline Sulfur, $\%$ of DM & $0.23 \pm 0.01$ & $0.23 \pm 0.01$ & $0.25 \pm 0.01$ & $0.23 \pm 0.01$ \\
\hline Sodium, $\%$ of DM & $0.49 \pm 0.05$ & $0.49 \pm 0.02$ & $0.49 \pm 0.04$ & $0.46 \pm 0.03$ \\
\hline Chloride ion, $\%$ of DM & $0.39 \pm 0.01$ & $0.39 \pm 0.02$ & $0.41 \pm 0.05$ & $0.39 \pm 0.02$ \\
\hline Iron, $\mathrm{mg} / \mathrm{kg}$ of $\mathrm{DM}$ & $306 \pm 33$ & $310 \pm 36$ & $275 \pm 14$ & $274 \pm 14$ \\
\hline Copper, $\mathrm{mg} / \mathrm{kg}$ of DM & $18 \pm 0.7$ & $17 \pm 1.1$ & $17 \pm 1.2$ & $16 \pm 0.8$ \\
\hline Manganese. $\mathrm{mg} / \mathrm{kg}$ of $\mathrm{DM}$ & $61 \pm 4$ & $68 \pm 2$ & $60 \pm 8$ & $64 \pm 5$ \\
\hline Zinc, $\mathrm{mg} / \mathrm{kg}$ of $\mathrm{DM}$ & $101 \pm 20$ & $93 \pm 3$ & $107 \pm 30$ & $88 \pm 6$ \\
\hline
\end{tabular}

${ }^{1}$ Diets containing either conventional corn silage (CON) or brown midrib corn silage (BM3) with either sulfate trace minerals (STM) or hydroxy trace minerals (HTM).

${ }^{2}$ Diets were analyzed for $\mathrm{DM}$ at $105^{\circ} \mathrm{C} ; \mathrm{n}=44$ for each diet. For all other analyses, $\mathrm{n}=4$.

${ }^{3}$ Amylase NDF on an OM basis.

${ }^{4}$ Ethanol-soluble carbohydrates.

and trace minerals was not significant $(P=0.11)$ for DMI. Cows fed the BM3 diets had greater $(P=0.02)$ DMI than cows fed the CON diets (28.1 vs. $27.5 \mathrm{~kg} / \mathrm{d})$. Cows fed the HTM diets had greater $(P=0.01)$ DMI than cows fed the STM diets $(28.1$ vs. $27.5 \mathrm{~kg} / \mathrm{d})$. The difference in intake between cows fed the BM3 and CON diets was expected, because the BM3 diets had greater in vitro digestibility of aNDFom and lower indigestible
NDF. In similar studies, cows fed diets with BM3 compared with conventional corn silage had greater DMI and lower rumen fill, believed to be related to a lower indigestible fiber fraction and greater passage rates of fiber from the rumen (Oba and Allen, 1999a, 2000a,c; Hassanat et al., 2017).

It is unlikely that the difference in starch content between the BM3 and CON diets had a major influence

Table 7. Data (mean $\pm \mathrm{SD}$ ) characterizing the fiber fractions of diets fed to lactating Holstein cows

\begin{tabular}{|c|c|c|c|c|}
\hline \multirow[b]{3}{*}{ Item } & \multicolumn{4}{|c|}{$\operatorname{Diet}^{1}$} \\
\hline & \multicolumn{2}{|c|}{$\mathrm{CON}$} & \multicolumn{2}{|c|}{ BM3 } \\
\hline & STM & HTM & STM & HTM \\
\hline 4-wk period composite samples, $n$ & 4 & 4 & 4 & 4 \\
\hline aNDFom, ${ }^{2} \%$ of DM & $36.3 \pm 2.1$ & $36.0 \pm 2.1$ & $32.1 \pm 0.9$ & $32.0 \pm 0.9$ \\
\hline 30-h aNDF digestibility, $\%$ of aNDFom & $56.0 \pm 2.4$ & $55.3 \pm 4.4$ & $61.9 \pm 2.1$ & $62.0 \pm 2.0$ \\
\hline Undigested NDFom at $30 \mathrm{~h}, \%$ of DM & $15.9 \pm 0.2$ & $16.0 \pm 0.8$ & $12.2 \pm 0.5$ & $12.1 \pm 0.4$ \\
\hline Undigested NDFom at $120 \mathrm{~h}, \%$ of DM & $9.3 \pm 0.5$ & $9.4 \pm 0.6$ & $7.6 \pm 0.2$ & $7.5 \pm 0.3$ \\
\hline Undigested NDFom at $240 \mathrm{~h}, \%$ of DM & $8.6 \pm 0.3$ & $8.6 \pm 0.4$ & $6.9 \pm 0.2$ & $6.9 \pm 0.1$ \\
\hline Potentially digestible NDF, ${ }^{3} \%$ of aNDFom & $76.3 \pm 1.0$ & $76.1 \pm 0.9$ & $78.4 \pm 0.5$ & $78.2 \pm 0.6$ \\
\hline
\end{tabular}

${ }^{1}$ Diets containing either conventional corn silage (CON) or brown midrib corn silage (BM3) with either sulfate trace minerals (STM) or hydroxy trace minerals (HTM).

${ }^{2}$ aNDFom $=$ amylase NDF on an OM basis.

${ }^{3}$ Potentially digestible NDF $=$ aNDFom - undigested NDFom at $240 \mathrm{~h}$. 
Table 8. Analyzed concentrations of supplemental and dietary copper, manganese, and zinc in diets fed to lactating Holstein cows

\begin{tabular}{|c|c|c|c|c|}
\hline \multirow[b]{3}{*}{ Item } & \multicolumn{4}{|c|}{ Diet $^{1}$} \\
\hline & \multicolumn{2}{|c|}{$\mathrm{CON}$} & \multicolumn{2}{|c|}{ BM3 } \\
\hline & STM & HTM & STM & HTM \\
\hline \multicolumn{5}{|c|}{ Supplemental mineral concentration, ${ }^{2} \mathrm{mg} / \mathrm{kg}$ of $\mathrm{DM}$} \\
\hline Copper & 10.6 & 10.5 & 9.2 & 8.9 \\
\hline Manganese & 41.5 & 41.2 & 41.2 & 39.6 \\
\hline Zinc & 64.3 & 63.8 & 63.2 & 60.8 \\
\hline \multicolumn{5}{|c|}{ Total dietary concentration, $\mathrm{mg} / \mathrm{kg}$ of $\mathrm{DM}$} \\
\hline Copper & 17.5 & 17.1 & 17.1 & 16.4 \\
\hline Manganese & 60.5 & 68.4 & 59.9 & 63.5 \\
\hline Zinc & 100.9 & 93.2 & 107.2 & 87.9 \\
\hline \multicolumn{5}{|c|}{ Total dietary mineral, $\mathrm{mg} / \mathrm{d}$} \\
\hline Copper & 493 & 469 & 468 & 458 \\
\hline Manganese & 1,671 & 1,877 & 1,650 & 1,830 \\
\hline Zinc & 2,767 & 2,567 & 2,943 & 2,517 \\
\hline \multicolumn{5}{|c|}{ Supplemental mineral, $\%$ of total dietary mineral } \\
\hline Copper & 60.6 & 61.6 & 53.9 & 54.0 \\
\hline Manganese & 68.6 & 60.3 & 68.8 & 62.4 \\
\hline Zinc & 63.7 & 68.5 & 58.9 & 69.1 \\
\hline
\end{tabular}

${ }^{1}$ Diets containing either conventional corn silage (CON) or brown midrib corn silage (BM3) with either sulfate trace minerals (STM) or hydroxy trace minerals (HTM).

${ }^{2}$ Concentrations based on treatment average DMI.

on DMI, because physical fill from forage NDF is a primary factor reducing DMI (Allen, 2000). To further support this, in previous research with diets varying in starch content between 3 and $8 \%$, no differences in DMI or milk production were reported (Voelker and Allen, 2003; Dann et al., 2014).

In contrast, Faulkner and Weiss (2017) did not report a difference in DMI between diets with sulfate or hydroxy trace minerals in forage- or byproduct-based diets. The difference between the studies could have been due to source of fiber, because Faulkner and Weiss (2017) used corn silage (44\% of DM) and alfalfa silage (20\% of DM) in the forage-based diets and corn silage ( $20 \%$ of DM), alfalfa silage ( $15 \%$ of DM), and fiber from byproducts $(54.2 \%$ of DM) in the byproduct-based diets. In contrast, in our study the majority of forage

Table 9. Particle size distribution (mean \pm SD) of the diets $(n=4)$ fed to lactating Holstein cows

\begin{tabular}{|c|c|c|c|c|}
\hline \multirow[b]{3}{*}{ Item } & \multicolumn{4}{|c|}{$\operatorname{Diet}^{1}$} \\
\hline & \multicolumn{2}{|c|}{$\mathrm{CON}$} & \multicolumn{2}{|c|}{ BM3 } \\
\hline & STM & HTM & STM & HTM \\
\hline \multicolumn{5}{|l|}{ Particle size, $\%$ of DM } \\
\hline$>19.00 \mathrm{~mm}$ & $0.0 \pm 0.0$ & $0.0 \pm 0.0$ & $0.1 \pm 0.1$ & $0.0 \pm 0.1$ \\
\hline 13.20 to $19.00 \mathrm{~mm}$ & $0.3 \pm 0.2$ & $0.1 \pm 0.1$ & $1.0 \pm 0.8$ & $1.7 \pm 1.1$ \\
\hline 9.50 to $13.20 \mathrm{~mm}$ & $1.6 \pm 0.3$ & $2.1 \pm 0.8$ & $4.4 \pm 0.8$ & $4.2 \pm 1.0$ \\
\hline 6.70 to $9.50 \mathrm{~mm}$ & $12.1 \pm 1.5$ & $11.1 \pm 2.0$ & $16.0 \pm 2.6$ & $16.5 \pm 2.0$ \\
\hline 4.75 to $6.70 \mathrm{~mm}$ & $12.2 \pm 0.2$ & $11.7 \pm 0.1$ & $12.8 \pm 0.8$ & $12.4 \pm 0.5$ \\
\hline 3.35 to $4.75 \mathrm{~mm}$ & $14.3 \pm 0.7$ & $13.7 \pm 0.2$ & $10.5 \pm 0.9$ & $11.0 \pm 0.8$ \\
\hline 2.36 to $3.35 \mathrm{~mm}$ & $10.6 \pm 0.4$ & $10.4 \pm 0.4$ & $8.2 \pm 0.8$ & $7.9 \pm 0.6$ \\
\hline 1.18 to $2.36 \mathrm{~mm}$ & $16.1 \pm 0.4$ & $16.2 \pm 0.9$ & $15.3 \pm 1.4$ & $15.1 \pm 1.3$ \\
\hline 0.60 to $1.18 \mathrm{~mm}$ & $17.2 \pm 0.9$ & $18.5 \pm 1.2$ & $15.8 \pm 1.5$ & $15.3 \pm 1.8$ \\
\hline 0.30 to $0.60 \mathrm{~mm}$ & $11.2 \pm 1.2$ & $11.9 \pm 1.2$ & $11.1 \pm 0.9$ & $10.9 \pm 0.3$ \\
\hline$<0.30 \mathrm{~mm}$ & $4.3 \pm 0.9$ & $4.2 \pm 0.8$ & $4.8 \pm 0.6$ & $4.9 \pm 0.5$ \\
\hline $\operatorname{pef}^{2}$ & $0.67+0.02$ & $0.66+0.02$ & $0.68+0.02$ & $0.69+0.02$ \\
\hline peNDF, ${ }^{3} \%$ of DM & 24.3 & $\begin{array}{l}0.00 \perp 0.02 \\
23.8\end{array}$ & 21.8 & $\begin{array}{l}0.09 \perp 0.02 \\
22.1\end{array}$ \\
\hline
\end{tabular}

${ }^{1}$ Diets containing either conventional corn silage (CON) or brown midrib corn silage (BM3) with either sulfate trace minerals (STM) or hydroxy trace minerals (HTM).

${ }^{2}$ Physical effectiveness factor, $\%$ of $\mathrm{DM} \geq 1.18 \mathrm{~mm}$; based on assumptions in Mertens (1997).

${ }^{3}$ Physically effective neutral detergent fiber. 
Table 10. Least squares means of intake and BW data from lactating Holstein cows $(\mathrm{n}=14)$

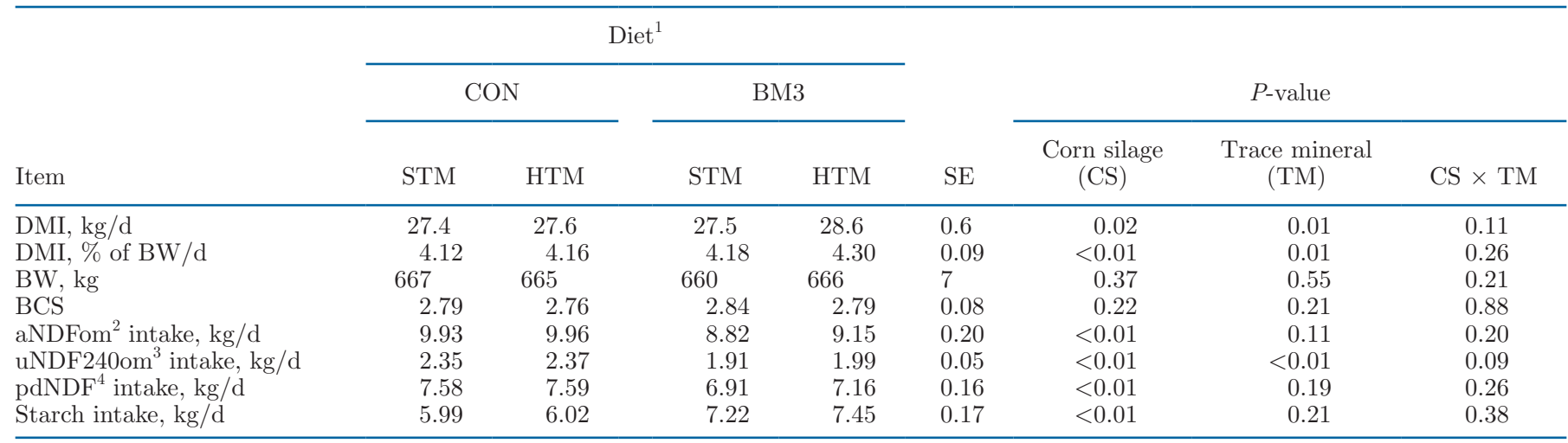

${ }^{1}$ Diets containing either conventional corn silage (CON) or brown midrib corn silage (BM3) with either sulfate trace minerals (STM) or hydroxy trace minerals (HTM).

${ }^{2}$ Amylase-modified NDF on an OM basis.

${ }^{3}$ Undigested NDF at $240 \mathrm{~h}$ of in vitro fermentation.

${ }^{4}$ Potentially digestible NDF $=$ aNDFom - undigested NDFom at $240 \mathrm{~h}$.

was corn silage ( $55 \%$ of DM), with a small amount of chopped wheat straw ( $2 \%$ of DM). The difference between the studies also could have been due to greater DMI and milk production in our study compared with Faulkner and Weiss (2017; 27.8 vs. $24.2 \mathrm{~kg} / \mathrm{d} ; 45.8$ vs. $33.6 \mathrm{~kg} / \mathrm{d}$, respectively).

Body weight and BCS did not differ among treatments $(P>0.10$; Table 10). Cows fed the CON diet had greater $(P<0.01)$ aNDFom and pdNDF intakes than cows fed the BM3 diets $(9.9$ vs. $8.9 \mathrm{~kg} / \mathrm{d} ; 7.6$ vs. $7.0 \mathrm{~kg} / \mathrm{d}$, respectively). We found a tendency for a corn silage $\times$ trace mineral interaction $(P=0.09)$ on uNDF240om intake. The uNDF240om intake was lower for cows fed STM compared with HTM in the BM3 diets (1.91 vs. $1.99 \mathrm{~kg} / \mathrm{d}$ ), whereas uNDF240om intake was not greatly affected by the source of trace minerals in the CON diets (2.35 vs. $2.37 \mathrm{~kg} / \mathrm{d}$ ). Cows fed the BM3 diets had lower uNDF240om intake than cows fed the CON diets (1.95 vs. $2.36 \mathrm{~kg} / \mathrm{d}$ ), because of a lower indigestible fraction of NDF in the BM3 corn silage. In agreement, Oba and Allen (2000b) reported that cows fed diets based on BM3 corn silage had lower indigestible NDF intake than cows fed diets based on conventional corn silage. Consumption of less uNDF240om is associated with the greater DMI we observed in the present study for cows fed the BM3 versus the CON diets. Cows fed the BM3 diets had greater $(P<0.01)$ starch intake than cows fed the CON diets $(7.3$ vs. $6.0 \mathrm{~kg} / \mathrm{d})$ because the starch content of the CON corn silage decreased over the course of the experiment.

Milk production and composition measures are presented in Table 11. Milk yield and ECM were greater for cows fed the BM3 diets $(P<0.01$ and $P=0.02$, respectively). With the greater feed intake and dietary starch content for cows fed the BM3 diets, it is not surprising that they produced more milk than cows fed the CON diets. Yield and concentration of milk fat and milk protein content were unaffected $(P>0.10)$ by corn silage or trace mineral sources. Similarly, Faulkner and Weiss (2017) reported no effect of trace minerals on milk fat and protein yield or concentration when feeding HTM versus STM. We found a tendency for a corn silage $\times$ trace mineral interaction on milk protein yield $(P=0.08)$ and milk lactose yield $(P=0.10)$, driven by differences in milk production. Milk lactose content had a tendency $(P=0.07)$ to be greater for cows fed the BM3 diets (4.59 vs. $4.57 \%$ ), although this difference was slight. The de novo, mixed origin, and preformed fatty acids were unaffected $(P>0.10)$ by corn silage or trace minerals (Table 11).

Feed efficiency, when expressed as milk yield per DMI, was greater $(P<0.01)$ for cows fed the BM3 diets than for cows fed the CON diet (1.68 vs. 1.63 $\mathrm{kg} / \mathrm{kg}$ ). However, feed efficiency expressed as ECM per DMI was unaffected $(P=0.43)$ by corn silage or trace minerals. This finding was in agreement with a similar study that compared BM3 versus conventional corn silage and reported no difference in feed efficiency when expressed as ECM per DMI (Hassanat et al., 2017).

\section{Total-Tract Nutrient Digestibility}

Total-tract digestibility of DM, OM, aNDFom, pdNDF, and starch is presented in Table 12. Cows fed the BM3 diets had greater $(P<0.05)$ total-tract digestibility of DM and OM than cows fed the CON diets ( 72.8 vs. $71.1 \%$ of DM; 74.1 vs. $72.3 \%$ of DM). Cows fed the BM3 diets digested more $(P<0.01)$ DM than cows fed the CON diets (20.4 vs. $19.6 \mathrm{~kg} / \mathrm{d})$. Cows fed 
Table 11. Least squares means of lactation performance data from lactating Holstein cows $(\mathrm{n}=14)$

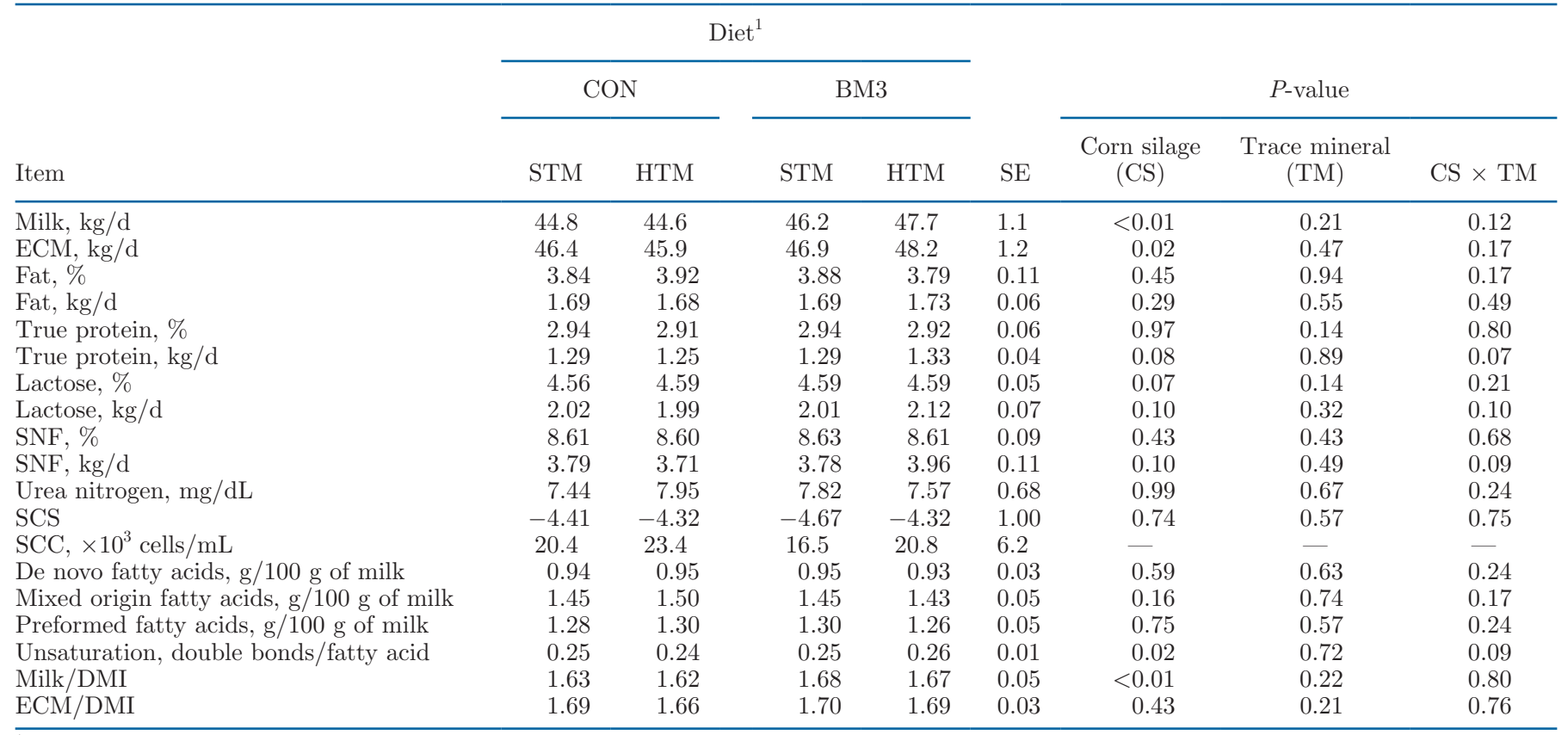

${ }^{1}$ Diets containing either conventional corn silage (CON) or brown midrib corn silage (BM3) with either sulfate trace minerals (STM) or hydroxy trace minerals (HTM).

the HTM diets digested more $(P=0.02)$ DM than cows fed the STM diets (20.3 vs. $19.7 \mathrm{~kg} / \mathrm{d})$. The differences in DM digestibility can be explained by the difference in digestibility of the corn silage, because the indigestible fraction was lower in BM3 corn silage than in CON corn silage (Table 3). In contrast, similarly designed studies found no differences in total-tract digestibility of $\mathrm{DM}$ and $\mathrm{OM}$ between cows fed diets with BM3 or conventional corn silage (Oba and Allen, 2000c; Has- sanat et al., 2017). However, for the present study, corn silage was the main forage (making up $96 \%$ of the forage), whereas for the other trials corn silage content made up 90\% (Hassanat et al., 2017) and 81\% (Oba and Allen, 2000c) of the forage.

Oba and Allen (2000c) reported no effect of dietary NDF content for total-tract digestibility of DM or OM. The low NDF diets had an average NDF content of $28.9 \%$ of DM and a starch concentration of $37.4 \%$ of

Table 12. Total-tract digestibility data for lactating Holstein cows $(\mathrm{n}=14)$

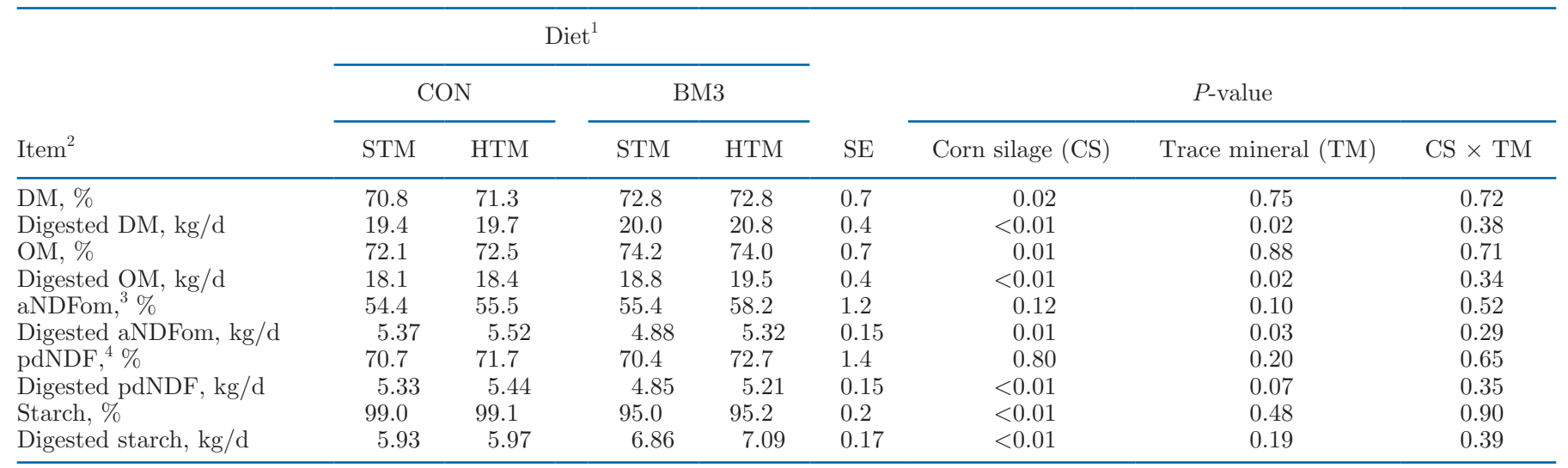

${ }^{1}$ Diets containing either conventional corn silage $(\mathrm{CON})$ or brown midrib corn silage (BM3) with either sulfate trace minerals (STM) or hydroxy trace minerals (HTM).

${ }^{2}$ Values are ash-corrected.

${ }^{3}$ Amylase-modified NDF on an OM basis.

${ }^{4}$ Potentially digestible NDF $=$ aNDFom - undigested NDFom at $240 \mathrm{~h}$. 
DM compared with the higher-NDF diets, which had an NDF content of $37.9 \%$ and an average starch concentration of $26.5 \%$ of DM. This study by Oba and Allen $(2000 \mathrm{c})$ had even greater starch content differences than our study and saw no effect on total-tract digestibility of DM, so we believe the response in total-tract DM or OM digestibility was more of an effect of fiber than starch.

The total-tract digestibility of pdNDF was unaffected $(P>0.10)$ by corn silage or trace minerals. Cows fed the CON diets digested more pdNDF than cows fed the BM3 diets ( 5.4 vs. $5.0 \mathrm{~kg} / \mathrm{d} ; P=0.01)$. As well, cows fed the HTM diets had a tendency to digest more pdNDF than cows fed the STM diets $(5.3$ vs. $5.1 \mathrm{~kg} / \mathrm{d} ; P=$ 0.07 ). The digested aNDFom and pdNDF were very similar in amounts, because only the pdNDF within the aNDFom can be digested (Waldo et al., 1972).

Cows fed the CON diets had greater $(P<0.01)$ totaltract starch digestibility than cows fed the BM3 diets (99.0 vs. $95.1 \%$ of DM). In agreement with our findings, Ferraretto and Shaver (2015) reported that cows fed BM3 corn silage-based diets had lower total-tract starch digestibility than cows fed conventional corn silage-based diets. The diets based on BM3 corn silage could have had lower total-tract starch digestibility due to faster passage rate or greater kernel vitreousness (Oba and Allen, 2000c; Ferraretto and Shaver, 2015). Even with the greater total-tract starch digestibility, cows fed the CON diet had less digested starch than cows fed the BM3 diets $(6.0$ vs. $6.9 \mathrm{~kg} / \mathrm{d} ; P<0.01)$ because of a lower starch intake (Table 10).

Cows fed the HTM diets had a tendency $(P=0.10)$ for greater total-tract digestibility of aNDFom than cows fed STM diets (56.9 vs. $54.9 \%$ of DM). Cows fed the $\mathrm{CON}$ diets digested $(P=0.01)$ more aNDFom than cows fed the BM3 diets (5.4 vs. $5.1 \mathrm{~kg} / \mathrm{d})$. Cows fed the HTM diets digested more $(P=0.03)$ aNDFom than cows fed the STM diets (5.4 vs. $5.1 \mathrm{~kg} / \mathrm{d}$ ). In agreement with our findings, Faulkner and Weiss (2017) reported greater total-tract digestibility of aNDFom for cows fed diets with hydroxy trace minerals than cows fed diets with sulfate trace minerals in either forage- or byproduct-based diets.

The published literature offers little to explain the effects of trace mineral source on fiber digestion (Martinez and Church, 1970). However, solubility does vary among sources of trace minerals and can affect rumen fermentation by harming cellulolytic bacteria or binding to fiber fractions (Faulkner et al., 2017; Torre et al., 1991). Rate of passage is affected by particle size, density, buoyancy, and entanglement of particles in the fiber digesta mat (Allen and Mertens, 1988; Kammes and Allen, 2012). If trace minerals bind with fiber fractions, this could slow the rate of digestion or interfere with microbial attachment, altering the density and buoyancy of the particle, and potentially affecting the passage of undigested fiber from the rumen.

Oba and Allen (1999b) reported that a 1-unit increase in vivo total-tract NDF digestibility of TMR was associated with a $0.42-\mathrm{kg}$ increase in DMI. The $2.0 \%$ difference in total-tract digestibility of aNDFom between cows fed the HTM and STM diets in the present study would equate to a $0.84-\mathrm{kg}$ increase in DMI, which could explain the $0.6-\mathrm{kg}$ difference observed in DMI for cows fed these diets.

\section{Chewing Behaviors}

Chewing behaviors are presented in Table 13. Eating time expressed as minutes per day or minutes per kilogram of DMI was unaffected $(P>0.10)$ by corn silage or trace mineral. This was not surprising, because the diets were very similar in particle size. We found a tendency for a corn silage $\times$ trace mineral interaction $(P=0.08)$ on rumination time, indicating that the difference among the trace minerals for rumination time was greater in BM3 diets. Cows fed the CON diets ruminated longer during the day, expressed as minutes per kilogram of DMI, than cows fed the BM3 diets $(P$ $<0.01)$. Meal length was unaffected $(P>0.10)$ by corn silage or trace mineral. Meal bouts were unaffected $(P$ $>0.10$ ) by corn silage, but we found a tendency for cows fed the HTM diets to have more meal bouts per day than cows fed the STM diets (11.7 vs. 11.2 bouts/d; $P=0.06$ ). To our knowledge, this is the first study to investigate the effect of trace mineral source on meal behavior, and more research is needed before the biological significance of this response is understood.

In agreement with our findings, Oba and Allen (2000b) reported no difference in eating time, expressed as minutes per day or minutes per kilogram of DMI between cows fed diets based on conventional or BM3 corn silage, but they did find that cows fed diets with BM3 corn silage had a tendency to ruminate less when expressed as minutes per kilogram of DMI than cows fed the diets with conventional corn silage. Forages with greater in vitro fiber digestibility break down more rapidly in the rumen, and in theory would require less mastication to reach critical size to pass from the rumen. This presumably contributes to the greater passage rates observed for cows fed BM3 corn silage compared with conventional corn silage (Oba and Allen, 2000c).

\section{CONCLUSIONS}

This study evaluated the effect of sources of corn silage (CON vs. BM3) and trace minerals (STM vs. 
Table 13. Least squares means of behavior data for lactating Holstein cows $(\mathrm{n}=14)$

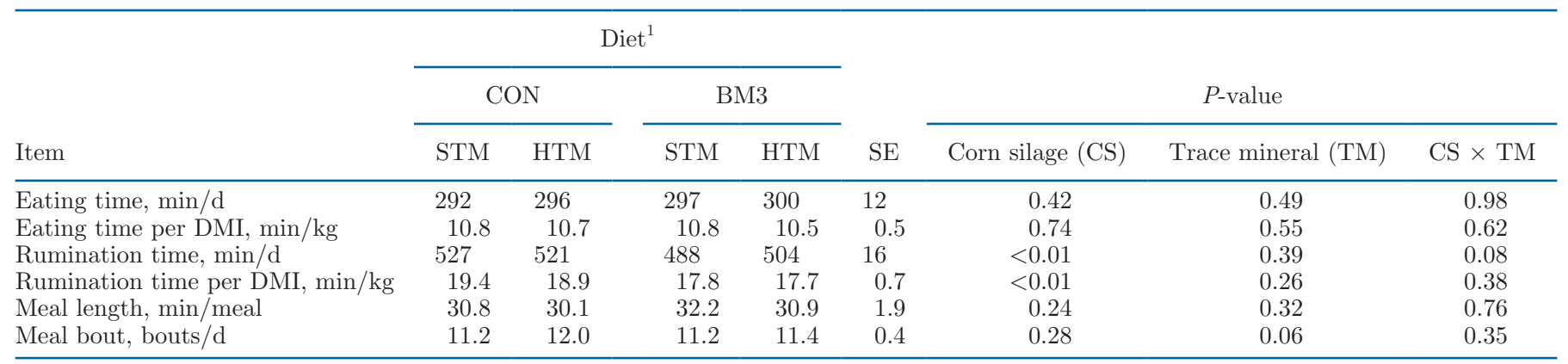

${ }^{1}$ Diets containing either conventional corn silage (CON) or brown midrib corn silage (BM3) with either sulfate trace minerals (STM) or hydroxy trace minerals (HTM).

HTM) on lactational performance, total-tract fiber digestibility, and chewing behaviors in Holstein cows. Cows fed the BM3 diets had greater DMI and ECM production than cows fed the CON diets. The source of trace minerals had an effect on DMI: cows fed the HTM diets had greater DMI than cows fed the STM diets. This difference in DMI between the HTM and STM diets can be partially accounted for by the difference in total-tract digestibility of aNDFom. Cows fed the BM3 diets ruminated less than cows fed the CON diets. Corn silage with greater in vitro NDF digestibility, lower uNDF240om, and greater starch content allowed for improved DMI and milk production. The sources of trace mineral and corn silage can influence DMI and total-tract digestibility of aNDFom and should be taken into consideration when formulating diets for high-producing dairy cows.

\section{ACKNOWLEDGMENTS}

We thank Micronutrients USA LLC (Indianapolis, IN) for partially funding this experiment and the farm and research staff at the William H. Miner Agricultural Research Institute (Chazy, NY) for care of the cows. The authors have not stated any conflicts of interest.

\section{REFERENCES}

Allen, M. S. 2000. Effects of diet on short-term regulation of feed intake by lactating dairy cattle. J. Dairy Sci. 83:1598-1624. https:// doi.org/10.3168/jds.S0022-0302(00)75030-2.

Allen, M. S., and D. R. Mertens. 1988. Evaluating constraints on fiber digestion by rumen microbes. J. Nutr. 118:261-270. https://doi .org/10.1093/jn/118.2.261.

AOAC International. 2012. Official Methods of Analysis. 19th ed. AOAC International, Gaithersburg, MD.

Black, R. A., R. J. Grant, and P. D. Krawczel. 2016. Short communication: Short-term changes in stocking density did not alter meal characteristics of lactating Holstein dairy cattle. J. Dairy Sci. 99:6572-6577. https://doi.org/10.3168/jds.2015-9602.

Caldera, E., B. Weigel, V. N. Kucharczyk, K. S. Sellins, S. L. Archibeque, J. J. Wagner, H. Han, J. W. Spears, and T. E. Engle. 2019. Trace mineral source influences ruminal distribution of copper and zinc and their binding strength to ruminal digesta. J. Anim. Sci. 97:1852-1864. https://doi.org/10.1093/jas/skz072.

Cao, J., P. R. Henry, C. B. Ammerman, R. D. Miles, and R. C. Littell. 2000. Relative bioavailability of basic zinc sulfate and basic zinc chloride for chicks. J. Appl. Poult. Res. 9:513-517. https://doi .org/10.1093/japr/9.4.513.

Cotanch, K. W., R. J. Grant, M. E. Van Amburgh, A. Zontini, M. Fustini, A. Palmonari, and A. Formigoni. 2014. Applications of uNDF in ration modeling and formulation. Pages 114-131 in Proc. Cornell Nutr. Conf., Dept. Anim. Sci., Cornell Univ., Ithaca, NY.

Dann, H. M., H. A. Tucker, K. W. Cotanch, P. D. Krawczel, C. S. Mooney, R. J. Grant, and T. Eguchi. 2014. Evaluation of lower-starch diets for lactating Holstein dairy cows. J. Dairy Sci. 97:7151-7161. https://doi.org/10.3168/jds.2014-8341.

DuBois, M., K. A. Gilles, J. K. Hamilton, P. A. Rebers, and F. Smith. 1956. Colorimetric method for determination of sugars and related substances. Anal. Chem. 28:350-356. https://doi.org/10.1021/ ac60111a017.

Faulkner, M. J., N. R. St-Pierre, and W. P. Weiss. 2017. Effect of source of trace minerals in either forage- or by-product-based diets fed to dairy cows: 2. Apparent absorption and retention of minerals. J. Dairy Sci. 100:5368-5377. https://doi.org/10.3168/jds.2016 $-12096$

Faulkner, M. J., and W. P. Weiss. 2017. Effect of source of trace minerals in either forage- or by-product-based diets fed to dairy cows: 1. Production and macronutrient digestibility. J. Dairy Sci 100:5358-5367. https://doi.org/10.3168/jds.2016-12095.

Ferguson, J. D., D. T. Galligan, and N. Thomsen. 1994. Principal descriptors of body condition score in Holstein cows. J. Dairy Sci. 77:2695-2703. https://doi.org/10.3168/jds.S0022-0302(94)77212 $-\mathrm{X}$.

Ferraretto, L. F., and R. D. Shaver. 2015. Effects of whole-plant corn silage hybrid type on intake, digestion, ruminal fermentation, and lactation performance by dairy cows through a meta-analysis. J. Dairy Sci. 98:2662-2675. https://doi.org/10.3168/jds.2014-9045.

Genther, O. N., and S. L. Hansen. 2015. The effect of trace mineral source and concentration on ruminal digestion and mineral solubility. J. Dairy Sci. 98:566-573. https://doi.org/10.3168/jds.2014 -8624 .

Goering, H. K., and P. J. Van Soest. 1970. Forage Fiber Analyses (Apparatus, Reagents, Procedures, and Some Applications). Agric. Handbook No. 379. ARS-USDA, Washington, DC.

Hall, M. B. 2009. Analysis of starch, including maltooligosaccharides, in animal feeds: A comparison of methods and a recommended method for AOAC collaborative study. J. AOAC Int. 92:42-49.

Hassanat, F., R. Gervais, and C. Benchaar. 2017. Methane production, ruminal fermentation characteristics, nutrient digestibility, nitrogen excretion, and milk production of dairy cows fed conventional or brown midrib corn silage. J. Dairy Sci. 100:2625-2636. https:// doi.org/10.3168/jds.2016-11862.

Kammes, K. L., and M. S. Allen. 2012. Rates of particle size reduction and passage are faster for legume compared with cool-season grass, 
resulting in lower rumen fill and less effective fiber. J. Dairy Sci. 95:3288-3297. https://doi.org/10.3168/jds.2011-5022.

Krishnamoorthy, U., T. V. Muscato, C. J. Sniffen, and P. J. Van Soest. 1982. Nitrogen fractions in selected feedstuffs. J. Dairy Sci. 65:217-225. https://doi.org/10.3168/jds.S0022-0302(82)82180-2.

Martinez, A., and D. C. Church. 1970. Effect of various mineral elements on rumen cellulose digestion. J. Anim. Sci. 31:982-990. https://doi.org/10.2527/jas1970.315982x.

Maynard, L. A., J. K. Loosli, H. F. Hintz, and R. G. Warner. 1979 Digestive processes in different species. Pages 21-46 in Animal Nutrition. McGraw-Hill Inc., New York, NY.

Mertens, D. R. 1997. Creating a system for meeting the fiber requirements of dairy cows. J. Dairy Sci. 80:1463-1481. https://doi.org/ 10.3168/jds.S0022-0302(97)76075-2.

NRC. 2001. Nutrient Requirements of Dairy Cattle. 7th rev. ed. National Academy Press, Washington, DC.

Nousiainen, J., M. Rinne, M. Hellamaki, and P. Huhtanen. 2003. Prediction of the digestibility of the primary growth of grass silages harvested at different stages of maturity from chemical composition and pepsin-cellulase solubility. Anim. Feed Sci. Technol. 103:97-111. https://doi.org/10.1016/S0377-8401(02)00283-3.

Oba, M., and M. S. Allen. 1999a. Effects of brown midrib 3 mutation in corn silage on dry matter intake and productivity of high yielding dairy cows. J. Dairy Sci. 82:135-142. https://doi.org/10.3168/ jds.S0022-0302(99)75217-3.

Oba, M., and M. S. Allen. 1999b. Evaluation of the importance of the digestibility of neutral detergent fiber from forage: Effects on dry matter intake and milk yield of dairy cows. J. Dairy Sci. 82:589596. https://doi.org/10.3168/jds.S0022-0302(99)75271-9.

Oba, M., and M. S. Allen. 2000a. Effects of brown midrib 3 mutation in corn silage on productivity of dairy cows fed two concentration of dietary neutral detergent fiber: 1 . Feeding behavior and nutrient utilization. J. Dairy Sci. 83:1333-1341. https://doi.org/10.3168/ jds.S0022-0302(00)75000-4.

Oba, M., and M. S. Allen. 2000b. Effects of brown midrib 3 mutation in corn silage on productivity of dairy cows fed two concentration of dietary neutral detergent fiber: 2. Chewing activities. J. Dairy Sci. 83:1342-1349. https://doi.org/10.3168/jds.S0022 -0302(00)75001-6.

Oba, M., and M. S. Allen. 2000c. Effects of brown midrib 3 mutation in corn silage on productivity of dairy cows fed two concentration of dietary neutral detergent fiber: 3. Digestibility and microbial efficiency. J. Dairy Sci. 83:1350-1358. https://doi.org/10.3168/jds .S0022-0302(00)75002-8.

Raffrenato, E., D. A. Ross, and M. E. Van Amburgh. 2018. Development of an in vitro method to determine rumen undigested aNDFom for use in feed evaluation. J. Dairy Sci. 101:9888-9900. https: //doi.org/10.3168/jds.2018-15101.
Shook, G. E. 1993. Genetic improvement of mastitis through selection on somatic cell count. Vet. Clin. North Am. Food Anim. Pract. 9:563-577. https://doi.org/10.1016/S0749-0720(15)30622-8.

Spears, J. W., E. B. Kegley, and L. A. Mullis. 2004. Bioavailability of copper from tribasic copper chloride and copper sulfate in growing cattle. Anim. Feed Sci. Technol. 116:1-13. https://doi.org/10 .1016/j.anifeedsci.2004.06.002.

Torre, M., A. R. Rodriguez, and F. Saura-Calixto. 1991. Effects of dietary fiber and phytic acid on mineral availability. Crit. Rev. Food Sci. Nutr. 30:1-22.

Tyrrell, H. F., and J. T. Reid. 1965. Prediction of the energy value of cow's milk. J. Dairy Sci. 48:1215-1223. https://doi.org/10.3168/ jds.S0022-0302(65)88430-2.

Van Soest, P. J., J. B. Robertson, and B. A. Lewis. 1991. Methods for dietary fiber, neutral detergent fiber, and nonstarch polysaccharides in relation to animal nutrition. J. Dairy Sci. 74:3583-3597. https://doi.org/10.3168/jds.S0022-0302(91)78551-2.

Voelker, J. A., and M. S. Allen. 2003. Pelleted beet pulp substituted for high-moisture corn: 1. Effects on feed intake, chewing behavior, and milk production of lactating dairy cows. J. Dairy Sci. 86:35423552. https://doi.org/10.3168/jds.S0022-0302(03)73959-9.

Waldo, D. R.. L. W. Smith, and E. L. Cox. 1972. Model of cellulose disappearance from the rumen. J. Dairy Sci. 55:125-129. https:// doi.org/10.3168/jds.S0022-0302(72)85442-0.

Wojciechowski, K. L., and D. M. Barbano. 2016. Prediction of fatty acid chain length and unsaturation of milk fat by mid-infrared milk analysis. J. Dairy Sci. 99:8561-8570. https://doi.org/10 $.3168 /$ jds.2016-11248.

Wojciechowski, K. L., C. Melilli, and D. M. Barbano. 2016. A proficiency test system to improve performance of milk analysis methods and produce reference values for component calibration samples for infrared milk analysis. J. Dairy Sci. 99:6808-6827. https:/ /doi.org/10.3168/jds.2016-10936.

Woolpert, M. E., H. M. Dann, K. W. Cotanch, C. Melilli, L. E. Chase, R. J. Grant, and D. M. Barbano. 2016. Management, nutrition, and lactation performance are related to bulk tank milk de novo fatty acid concentration on Northeastern US dairy farms. J. Dairy Sci. 99:8486-8497. https://doi.org/10.3168/jds.2016-10998.

\section{ORCIDS}

M. D. Miller (®) https://orcid.org/0000-0002-1448-6289

J. S. Lanier (ㄷ https://orcid.org/0000-0003-3043-7820

H. M. Dann ๑ https://orcid.org/0000-0002-7372-7011

R. J. Grant ๑ https://orcid.org/0000-0001-5797-9916 